\title{
Ketertarikan Mahasiswa Patani Melanjutkan Studi Pendidikan Islam di Indonesia
}

\author{
Sehat Sultoni Dalimunthe \\ lanawalakum@yahoo.co.id
}

\begin{abstract}
This research is motivated by curiosity about why Patani people choose to study in Indonesia, while Malaysia is a neighboring country of Patani which is geographically relatively close and also classified as advanced education. The object of research is the past and continues until now, so this study uses the total history method. To get research data, it is mostly used with the documentation method. The documentation method is complemented by the interview method. For Patani students and alumni who can still be found, the data collection techniques used are interviews and observations and are equipped with documentation methods. The results of the study show that the History of Islamic Studies of Patani students in Indonesia from 1963-2019 can be divided into three. First, in 1963-1991, where they studied only on the island of Java and were limited to the cities of Jakarta, Bandung, and Yogyakarta. Second, in 1992-2013, they expanded the study area to Medan and Banda Aceh. Third, in 2014-2019, they studied spread throughout Indonesia. In the first stage, it can be said that they chose the place to study because of the quality factor. In the second stage due to geographical proximity. While the third is because of the available scholarships.
\end{abstract}

Keyword: Indonesia, Islam, Patani, Student

\begin{abstract}
Abstrak
Penelitian ini dilatarbelakangi oleh rasa ingin tahu mengapa orang Patani memilih untuk belajar di Indonesia, sedangkan Malaysia adalah negara tetangga Patani yang secara geografis relatif dekat dan juga tergolong pendidikan yang maju. Objek penelitian masa lalu dan berlanjut sampai sekarang, maka penelitian ini menggunakan metode total history. Untuk mendapatkan data-data penelitian, lebih banyak digunakan dengan metode dokumentasi. Metode dokumentasi dilengkapi dengan metode wawancara. Untuk mahasiswa Patani dan para alumni yang masih dapat dijumpai digunakan teknik pengumpulan datanya dengan wawancara dan observasi dan dilengkapi dengan metode dokumentasi. Adapun hasil penelitian menunjukkan bahwa Sejarah Kajian Islam mahasiswa Patani di Indonesia dari tahun 1963-2019 dapat dibagi menjadi tiga. Pertama, pada tahun 1963-1991, di mana mereka belajar hanya di pulau Jawa dan terbatas di kota Jakarta, Bandung, dan Yogyakarta. Kedua, pada tahun 1992-2013, mereka memperluas wilayah studi ke Medan dan Banda Aceh. Ketiga, pada 2014-2019, mereka belajar tersebar di seluruh Indonesia. Pada tahap pertama, dapat dikatakan bahwa mereka memilih tempat belajar karena faktor kualitas. Pada tahap kedua karena kedekatan geografis. Sedangkan yang ketiga adalah karena adanya beasiswa yang tersedia.
\end{abstract}

Kata Kunci: Mahasiswa, Indonesia, Islam, Patani, 


\section{A. Pendahuluan}

Islam minoritas dalam sebuah negara selalu menarik untuk diperhatikan dan diteliti, tidak terkecuali Patani. Kerajaan Islam Patani menurut sejarahnya berdiri tahun 1387 (Al-Fatani, 1994) . Sejak tahun 1785 telah dikusai oleh Siam. Dalam sejarah Islam Patani, ulama-ulama bukan saja mengembangkan Islam di Patani, Malaysia, bahkan juga ke Indonesia (al-Fatani, 1994, hal. 135). Pada tahun 1902, dengan politik adu domba, Patani berhasil dipecah menjadi kerajaan-kerajaan kecil. Sejak itulah Kerajaan Siam berusaha mengganti identitas Kerajaan Patani yang Melayu dan Islam dengan identitas kultur Thai yang Budhis (Hasbullah, 2003, hal. 261). Dengan kekuasaan Kerajaan Siam terhadap Kerajaan Patani, maka Syariah dihapuskan dan pejabat-pejabat Thailand mulai dimasukkan dalam lembaga peradilan (Al-Fatani, 1994).

Pada kondisi politik yang tidak kondusif tersebut, maka mahasiswa yang berasal dari Patani berusaha kuliah di luar Negeri temasuk ke Indonesia. Pemerintah Thailand tidak menginginkan masyarakat Patani mengenal sejarah masa lalu mereka, Untuk itu buku-buku yang berhubungan dengan sejarah Patani tidak didapatkan di Patani. Jika Diketahui beredar, akan ditarik oleh pemerintah Thailand. Buku-buku sejarah masa lalunya biasanya didapatkan di luar Thailand, seperti Malaysia dan Indonesia pada umumnya. Yang menarik, dilihat dari letak geografis, Indonesia, khususnya pulau Jawa jauh dengan Patani Thailand, tetapi sejak tahun 1972, masyarakat Patani mulai kuliah di Indonesia, khususnya di pulau Jawa.

Tahun 2018, diketahui bahwa Indonesia menjadi destinasi kuliah mahasiswa Patani terbesar kedua setelah Mesir. Mereka itu pada umumnya kuliah di Perguruan Tinggi Agama Islam Negeri. Demikian kata Muhammad Hafizh bin Ismail, dosen Jamiah Islam Syeikh Dauh Abdullah al-Fathani, seorang alumni FKIP UMSU. Persatuan mahasiswa Patani berdiri di berbagai daerah di Indonesia, seperti di Semarang, Padang, Pekanbaru, Banda Aceh, Bandung, dan sebagainya. Mereka itu biasanya bergabung dalam sebuah organisasi. Nama organisasi Patani di Indonesia ada 16, yaitu Persatuan Mahasiswa Islam Patani Thailand Indonesia (PMIPTI); Himpunan Mahasiswa Patani Indonesia (HMPI); Thai Students of Southen Thailan (TSOS). Namanama organisasi lainnya: PERMIS, IMIPI, PMMPI, PMPI, IPMITI, THASINA, HIPPI, PMTINU, PEMITU, IMPS, BBM, IMPIPI, IMASEJ. Mereka itu menyebar di berbagai kota di Indonesia. 15 di daerah pulau jawa, yaitu Jakarta, Bandung, Yogyakarta, Surakarta, Semarang, Malang, Surabaya, Jember, Ponorogo, Mojokerto, Sidoarjo, Purwokerto, Kediri, Tulung Agung, Jepara. 9 di derah pulau Sumatera, yaitu Aceh, Medan, Padang 
Sidimpuan, Pekanbaru, Padang, Bukit Tinggi, Batu Sangkar, Jambi, dan Lampung. Dua di pulau Kalimantan, yaitu Samarinda dan Palangkaraya. Satu di Sulawesi, yaitu Makassar. Yang telah diketahui mereka berada di 27 kota di Indonesia.

Fenomena di atas melahirkan pertanyaan, kenapa mereka tidak memilih Malaysia sebagai destinasi studi Islam. Karena Malaysia adalah Negara tetangga yang lebih dekat dengan Patani khususnya Universitas Utara Malaysia Kedah (UUM), Universiti Malaysia Perlis (UNIMAP), Universitas Malaysia Kelantan (UMK), Universitas Sains Malaysia (USM) Penang. Sementara orang-orang Indonesia pun banyak yang memilih kuliah di Negara yang telah disebutkan tadi. Tentulah ada alasan-alasan mahasiswa Patani yang terdiri dari Yala, Patani, Naratiwat, dan Satun untuk memilih Indonesia sebagai desdinasi studi Islam.

Mahasiswa Patani yang pertama kali kuliah di Indonesia adalah Muhktar Yahya tahun 1963 di Universitas Indonesia jurusan Hubungan Internasional. Selanjutnya ada yang mengikuti jejaknya, tetapi mereka kuliah di Bandung. Gelombang ketiga yang datang dari Patani, mereka kuliah di Yogyakarta. Sampati tahun 1991. Mahasiswa Patani hanya kuliah di tiga kota di Indonesia, yaitu Jakarta, Bandung dan Yogyakarta. Sejak tahun 1992-2013 berkembanglah mereka kuliah di Medan dan Banda Aceh. Dua kota ini dipilih lebih pada kedekatan geografis dengan Patani. Untuk kepentingan akreditasi, sejak tahun 2014-sampai 2019, banyak mahasiswa Patani di rekrut untuk menjadi mahasiswa di PTKIN dan Universitas Muhammadiyah dan sebagian kecil di Perguruan Tinggi NU.

Oleh karena itu, hal ini menjadi sesuatu yang menarik untuk diteliti, bagaimana sejarah masuknya mahasiswa Patani di Indonesia, apa yang melatarbelakangi mereka memilih Indonesia tempat studi Islam, dan apa saja konsentrasi studi mereka itu. 


\section{B. Metode}

Jenis penelitian ini adalah kualitatif dengan metode riset sejarah. Untuk mendapatkan data-data penelitian, lebih banyak digunakan dengan metode dokumentasi. Metode dokumentasi dilengkapi dengan metode wawancara. Untuk mahasiswa Patani dan para alumni yang masih dapat dijumpai digunakan teknik pengumpulan datanya dengan wawancara dan observasi dan dilengkapi dengan metode dokumentasi. Analisis data dilakukan dengan tahapan reduksi data, penyajian data dan penarikan kesimpulan.

\section{Hasil dan Pembahasan}

Sejarah studi Islam mahasiswa Patani di Indonesia dapat dibagi tiga. Pertama, tahun 1963-1991, masa mereka hanya kuliah di pulau Jawa, yaitu di Jakarta, Bandung dan Jakarta. Kedua, tahun 1992-2012, masa mereka sudah mulai kuliah di Medan dan Banda Aceh. Ketiga, tahun 2013-2019 atau sampai sekarang, dimana mereka telah menyebar di seluruh Indonesia.

\section{Hasil}

\section{Sejarah Mahasiswa Patani di Pulau Jawa Tahun 1963-2019}

Tahun 1993-1991, mahasiswa Patani hanya kuliah di Jakarta, Bandung, dan Jakarta. Pada masa-masa integralisisi pendidikan pondok ke pemerintah Thailand, Mukhtar Muhammmad tahun 1963. Kehadirannya ke Indonesia, tepat pada masa akhir kehidupan Sarit Thanarat. Mukhtar Muhammad kuliah di UI jurusan Hubungan internasional (MPA, 2020).

Mukhtar Muhammad dari Sungai Padi Narathiwat adalah orang pertama kuliah di Indonesia. Narathiwat adalah sebuah provinsi sekarang di Selatan Thailand untuk tidak mengatakan Thailand Selatan berbatasan langsung dengan Negeri Kelantan. Kelantan dahulu sebelum dikuasai oleh Inggris termasuk Kerajaan Islam Patani. Dengan perjanjian Bangkok tahun 1910, Kelantan menjadi negara Malaysia. Kenyataan inilah menjadi dapat dipahami bahwa penduduk Kelantan umumnya berasal dari Patani. Kelantan kelak selain Kedah menjadi pusat studi Islam di Malaysia. Setelah Mukhtar Muhammad menjadi Sarjana Hubungan Internasional dari UI, ia kemudian bekerja Departemen Luar Negeri, sebagai Konsulat Jenderal Jeddah Arab Saudi (MPA, 2020).

Menarik melihat awal studi Mukhtar Muhammad tahun 1963, pada masa Integralisasi Pondok ke pendidikan pemerintah di Thailand. Setelah Mukhtar Muhammad tamat dari UI, Raja Thailand Sarit Thanarat menunjuknya menjadi 
Konsulat Jenderal di Jeddah. Penunjukan itu tentu atas dasar kemampuannyanya melaksanakan tugas kenegaraan itu. Penempatan di Jeddah, bisa juga mengindikasikan bahwa ia alumni dari salah satu Pondok di Patani yang telah menerima program intergrasi dari kurikulum pemerintah.

Perlu disampaikan bahwa di Patani banyak berdiri pondok dan sekaligus banyak melahirkan ulama-ulama. Hanya saja, ulama-ulama Patani banyak juga berdomisili di Kelantan, Kedah, dan Trengganu yang dulu pernah menjadi satu kesatuan dengan Kerajaan Islam Patani dan karena faktor politik ulama-ulama Provinsi Pattani, Yala, Narathiwat, Songkla, dan Setun banyak pindah ketiga wilayah tersebut yang notabene berbatasan langsung dengan Patani. Tidak menutup kemungkinan Mukhtar Muhammad adalah seorang anak mujahid Patani yang memiliki wawasan yang modern, sehingga ia diarahkan meneruskan pendidikan ke UI yang telah mapan sejak berdirinya tahun 1849, hampir 100 tahun sebelum kemerdekaan negara RI. Itulah sebabnya, Mukhtar Muhammad dari Patani tidak meneruskan ke IAIN Jakarta yang baru saja berdiri tahun 1963, saat ia datang ke Indonesia.

Secara logis, langkah Mukhtar Muhammad adalah terobosan yang hebat pada saat itu, apakah karena idenya sendiri, orang tua, maupuan orang lain. Di sisi lain pemilihan Jurusan Hubungan Internasional menunjukkan kemapanan wawasan siapapun yang mengarahkannya, sekaligus potensi akademiknya yang memadai mengingat sampai sekarang jurusan itu masih prestisius. Dua tahun setelah kedatangan Mukhtar Muhammad ke Indonesia untuk menimba ilmu di Universitas Indonesia, kemudian datang lima orang pemuda untuk belajar di Bandung. Tidak didapatkan informasi, apakah mereka datang karena ajakan Mukhtar Muhammad atau mereka punya inisiatif sendiri.

Mereka yang berlima itu, Ahmad Subarjo, Asyari Kampung Tanjung, Abdul Halim Kedai Jabat, Hasan Tayib, Husain Bonggal Renab. Dari lima nama itu terlihat jelas nama-nama Islamnya dan dua di antaranya justru kemungkinan punya asal usul dari Indonesia, yaitu Ahmad Subarjo yang kemungkinan berasal dari Jawa dan Asyari Kampung Tanjung yang kemungkinan berasal dari Sumatera Barat. Sebagaimana disebut di atas, bahwa orang yang pertama kali menempati Patani juga berasal dari orang Jawa. Kemudian orang Minang yang bersuku Tanjung, biasanya hidup ditepi pantai, sangat memungkinkan merantau lewat laut sampai ke Patani. Sewaktu peneliti berkunjung ke Patani, Usman Tanjung juga mengakui bahwa asal usulnya dari Sumatera Barat, tetapi ia tidak mengetahui darimana asal daerahnya secara spesifik. 
Tanjung, simbol suku Minang bisa juga seperti kasus Lukman Hakim Harahap, dosen UIN Surakarta, ternyata suku Jawa. Harahap adalah nama yang diberikan ayahnya karena fans terhadap penyanyi Ronto Harahap. Bisa juga seperti cerita Chairuman Harahap punya kawan di Universitas Padjajaran Nasution, ternyata juga buka Suku Batak. Nasution, nama yang diberikan ayahnya karena fans terhadap Jenderal Abdul Haris Nasution. Bisa juga seperti yang disampaikan oleh Dr. Zulli Umri, di UIN Bandung ada dosen bernama Hariman Surya Siregar dari Tasikmalaya ternyata suku Sunda. Nama itu diberi oleh ayahnya karena fans terhadap Bismar Siregar. Peneliti juga berjumpa dengan bapak Mushtafa Lubis di Camming Sulawesi Selatan, ayah dari kawan peneliti, orang Jawa Kudus yang tidak tahu kenapa ia bernama Lubis. Mungkin ini juga yang terjadi teman saya di Gontor yang bernama Safri Lubis menurut pengakuannya ia orang Minang bukan orang Batak.

Mereka berlima di atas, gelombang kedua mahasiswa Patani belajar di Indonesia, sebagian mereka belajar di Universitas Padjajaran yang berdiri tahun 1957. Dua tahun setelah Unpad berdiri baru berdiri ITB, 2 Maret 1959. Memang dengan nama de Techniche Hoogeschool te Bandung telah berdiri 3 Juli 1920. Tentulah mereka itu mustahil belajar di IAIN Bandung, sebab lembaga itu baru berdiri tahun 1968, seumur dengan berdirinya IAIN Padangsidimpuan. Dibandingkan dengan Universitas Indonesia yang berdiri tahun 1849, tentu UNPAD masih tergolong muda di saat itu. Justru karena faktor yang masih muda itulah mereka lebih mudah diterima jadi mahasiswa dibandingkan di UI. Sebagian lain sangat mungkin belajar di UNISBA, sebab lembaga itu berdiri tahun 1958 atau UNINUS yang berdiri tahun 1959. Kedua lembaga ini walaupun swasta, tetapi umurnya hampir berdekatan dengan Unpad. Entitas Universitas Islam tersebut, tentu menjadi daya tarik bagi mahasiswa Patani saat itu.

Nama Ahmad Subarjo, bisa saja bukan orang Indonesia, tetapi orang tuanya yang terinspirasi dengan Radeh Achmad Suoebardjo Djojoadisoerjo, seorang tokoh Kemerdekaan Indonesia Menteri Luar Negeri Indonesia yang pertama (1951-1952). Ahmad Subarjo bukan saja Menteri Luar Negeri Pertama RI, tetapi beliau juga penyusun teks Proklamasi Kemerdekaan Indonesia. Tokoh yang berpendidikan Leiden ini tidak mustahil tersohor bagi pembaca di Patani dan atas jasa-jasanya, diabadikan orang lain namanya. Setidaknya pembaca adalah orang yang berwawasan luas. Yang berwawasan luas lantas menyekolahkan anaknya di Indonesia pada saat itu tergolong maju. 
Gelombang kedua mahasiswa Patani datang keindonesia, besar kemungkinan didorong oleh interaksi Mukhtar Muhammad dengan kelima orang tersebut, mengingat pada masa itu, pasport hanya berlaku satu tahun. Setelah satu tahun tentulah diperpanjang. Memperpanjangnya pada saat itu bisa jadi ke Ibukota Thailand, yaitu Bangkok. Alternatif lain, diperpanjang di Kedutaan Thailand, yakni di Jakarta. Dengan peraturan perpanjangan pasport itu tentu mereka sempatkan untuk pulang kampung. Hubungan sesama Muslim di wilayah Patani boleh jadi lebih intim mengingat mereka menanggung derita yang sama dan ingin berjuang lewat dunia pendidikan, karena sebagian lain telah berjuang lewat senjata.

Pada tahun 1969, yaitu empat tahun setelah gelombang kedua datang ke Indonesia, kemudian datang 9 orang pemuda. Kali itu mereka belajar di Yogyakarta (MPA, 2020). Mereka yang sembilan itu tidak disebutkan namanya karena informan, yaitu penulis sejarah PMIPTI tahun 2011, dari Kampung Tok Janggut Merah mungkin tidak mengingat namanya lagi. Menarik untuk dicermati, ketiga kelombang kedatangan mahasiswa Patani di Indonesia kuliah di tiga tempat yang sampai sekarang dikenal maju dalam bidang pendidikan. Mereka yang kuliah di Yogyakarta mungkin saja di IAIN Sunan Kali Djaga. IAIN Sunan Kali Djaga berdiri 24 Agustus 1960. Memang cikal bakalnya telah dimulai di tahun 26 September 1951, yaitu PTAIN.(Maragustam, 2018). Sementara UGM berdiri 19 Desember 1949. Sangat memungkinkan mereka kuliah di dua perguruan tinggi tersebut. Besar juga kemungkinan mereka kuliah di Universitas Islam Indonesia, yang berdiri 8 Juli 1945.

Dari sisi geografis, ada perguruan tinggi yang lebih dekat dari Patani, yaitu Universitas Islam Sumatera Utara yang berdiri 7 Januari 1951, lebih awal dari UNISBA dan UNINUS, namun mereka tidak kuliah di tempat ini mengingat pada saat itu pendidikan yang bagus tersohor di Pulau Jawa dan bahkan sampai sekarang. Bisa juga pada saat itu, perjalanan dari laut lebih dekat juga ke Universitas Islam Riau yang telah berdiri 4 September 1962, namun Sumatera belum menjadi tujuan utama pendidikan pada saat itu. Pada waktu hampir bersamaan, pada tahun 1968 menurut informasi dari K.H. Hidayatullah Zarkasyi, orang Patani telah ada yang mondok di Pondok Modern Gontor. Beliau menyebutkan, mereka itu adalah anak-anak mujahid dari Patani. Di antara namanya adalah Abdul Rahman.

Dari sisi waktu, tahun 1968 dan 1969 bisa saja waktunya sama, tetapi informan ingatnnya ada yang keliru. Bisa jadi mereka yang 9 gelombang ketiga tidak semua kuliah, sebagian malah mondok di Pondok Modern Gontor, mengingat orang-orang Patani banyak juga yang mondok walaupun umurnya sudah sampai ke masa kuliah. 
Hal itu di Pondok Gontor sampai tahun 1990-an juga biasa. Peneliti berpendapat di antara yang 9 itu bisa saja sebagian ada yang mondok di Pondok Modern Gontor, mengingat jarak antara Yogyakarta dengan Ponorogo masih tergolong dekat dan bisa ditempuh lewat jalur darat. Kedekatan waktu tersebut memungkinkan itu cerita yang sama.

Setelah kedatangan gelombang ketiga tersebut di atas, secara terus menerus, tanpa terputus mahasiswa Patani setiap tahun ada yang kuliah di Indonesia (MPA, 2020). masa mereka menyebar di seluruh Organisasi adalah wadah yang mestinya wujud dalam dunia modern, apalagi bagi mahasiswa. Banyak organisasi mahasiswa di luar negeri yang berbasis negara, biasanya hanya satu. Contohnya di Mesir PPMI, Persatuan Pelajar dan Mahasiswa Indonesia. Organisasi yang berbasis hanya ada satu. Walaupun nama organisasi beberapa kali berubah, tapi organisasi berbasis negara hanya satu. Sementara organisasi pelajar berdasarkan daerah di Mesir, contohnya ada Keluarga Masyarakat Aceh (KMA), Kekeluargaan Pelajar Tapanuli dan Sekitarnya (KPTS), Ikatan Keluarga Pondok Modern Gontor (IKPM), dan sebagainya. Hal ini yang berbeda dengan organisasi mahasiswa Patani di Indonesia. Mahasiswa Patani memiliki 16 jenis nama organisasi di Indonesia. Di Indonesia berdiri 37 organisasi mahasiwa karena ada satu organisasi berada di berbagai kota.

\section{PMIPTI di Medan dan Banda Aceh 1992-2012}

PMIPTI adalah organisasi pertama yang berdiri sejak tahun 1972 ada di sembilan kota. Begitu juga Organisasi Thai Students juga ada di sembilan kota seluruh Indonesia. Sementara organisasi lainnya hanya ada satu nama per kota. Ada yang berbasis perguruan tinggi.

Mahasiswa Patani di setiap daerah berkumpul kost dalam satu tempat. Biasanya mereka menyewa rumah dan kemudian mereka tinggal dalam tempat yang sama. Karena mahasiswa Patani terdiri dari laki-laki dan perempuan, maka minimal mereka berapada pada dua rumah yang berdekatan lokasinya. Jika tidak cukup dalam satu rumah, mereka menyewa rumah lain. Yang jelas, mereka tidak menyewa dengan orang selain Patani. Karena faktor di atas, tidak sulit bagi peneliti untuk mengumpulkan data dari mereka yang masih aktif kuliah di Medan maupun di Banda Aceh. Hanya saja, faktor Covid 19, sebagian mereka ada yang sedang pulang ke Patani dan tidak bisa pulang kembali karena aturan negara dan diperkuat lagi sistem kuliah yang off line (daring). 
Untuk penelitian di PMIPTI Medan, peneliti mendapatkan informasi dan data yang lebih mendalam. Sebagaimana pengakuan mahasiswa dan mahasiswi Patani yang kuliah di Medan, sejarah datangnya mahasiswa Patani di kota Medan ada hubungannya dengan mahasiswa Patani yang kuliah di Pulau Jawa. Jika dihitung dari awal mula datangnya Mukhtar Muhammad, mahasiswa Patani yang berasal dari Sungai Padi Narathiwat ke Jakarta, kuliah di Universitas Indonesia tahun 1963 sampai 1992, yaitu 25 tahun. Sepanjang 25 tahun, mahasiswa Patani hanya kuliah di Pulau Jawa, yaitu di Jakarta, Bandung, dan Yogyakarta.

Dari kedekatan geografis dan transfortasi, penerbangan dari Bangkok ke Jakarta. Dari Jakarta bisa ditempuh lewat darat ke Bandung. Semakin menjauh mereka ke Yogyakarta. Tiga kota itu memang maju dalam bidang pendidikan sampai sekarang. Jakarta dengan UI, Universitas tertua di Indonesia. UNISBA dan UNINUS dua universitas Islam yang ada di Bandung selain Undap, dan Yogyakarta dengan UGM, UII, dan IAIN menjadikan tiga kota tersebut sangat wajar menjadi destinasi akademik bagi mahasiswa Patani sepanjang 25 tahun.

Sampai tahun 1991, tentu mahasiswa Patani telah banyak masuk IAIN di tiga kota tersebut, yaitu di IAIN Syarif Hidayatullah Jakarta, IAIN Sunan Gunung Djati, dan IAIN Sunan Kali Djaga. Mengingat proses perkuliah di tiga kota itu, termasuk di IAIN sudah ketat dan selektif. Ada saja mahasiswa yang terkendala dalam proses penyelesaiannya. Pada saat yang sama, kemungkinan di Medan, tingkat selektifitas masih lebih rendah dari ketiga kota teresebut, termasuk di IAIN.

Mahasiswa Patani yang dijumpai di Medan pada saat penelitian ini sepakat mengatakan bahwa pertama yang kuliah di Medan dari Patani 7 orang laki-laki. Jumlah dan jenis kelamin mereka yang datang pertama ke Medan itu biasa disebut dan diperbincangkan secara turun-temurun tanpa ada perbedaan pendapat. Jumlah yang tujuh laki-laki diabadikan dalam Mars PMIPT Medan (Safrida Rusma Nasution, Skripsi USU, h. 41).

Untuk melihat Medan sebagai kota Pendidikan tinggi dapat kita lihat bahwa Universitas Sumatera Utara telah berdiri 20 November 1957. USU lebih muda dua bulan dari Unpad yang berdiri 11 September 1957. Enam tahun berikutnya berdirilah Institut Keguruan dan Ilmu Pendidikan (IKIP) Medan, 23 Juni 1963 yang sekarang jadi UNIMED. Sepuluh tahun berikutnya berdirilah IAIN Sumatera Utara tahun 1973, lebih muda dari dari IAIN Padangsidimpuan 5 tahun.(Rusma, 2019). Sebenarnya di Medan bukanlah Perguruan Tinggi Negeri yang pertama berdiri, 7 Januari 1951, telah berdiri Universitas Islam Sumatera Utara, lebih tua 6 tahun dari USU, bahkan UMSU lebih tua 
hampir 9 bulan dari USU, yang berdiri 27 Februari 1957. Universitas al-Wasliyah saja lebih muda 6 bulan dari USU yang berdiri 18 Mei 1958.

Dari data tersebut di atas, maka bisa disimpulkan perguruan tinggi di Medan telah lebih awal berdiri daripada perguruan tinggi di Bandung. Faktor kedekatan geografis dengan Jakarta, bisa jadi Bandung tidak menjadi prioritas bagi pemerintah. Memang untuk kepentingan Belanda, ITB yang berdiri tahun 1959, cikal bakalnya telah berdiri tahun 1920. Namun secara faktual mahasiswa Patani ke Indonesia belajar di Perguruan Tinggi Umum dan lebih khusus Perguruan Tinggi Islam, maka Medan jauh lebih duluan menjadi Kota Perguruan Tinggi dibanding Bandung. Berbeda dengan Yogyakarta yang lebih tua dari Medan. Namun brand dari Pulau Jawa sebagai destinasi belajar di Perguruan Tinggi lebih bagus dari Pulau Sumatera.

Kedatangan mahasiswa Patani ke Pulau Jawa, khususnya ke Jakarta, Bandung, Dan Yogyaakarta bisa dikatagorikan faktor kualitas pendidikan dan lingkungan yang telah maju. Ibukota yang berada di Pulau Jawa yang pada saat itu bersifat sentralistik sangat mendukung kemajuan Pulau Jawa termasuk dalam bidang pendidikan. Padahal dilihat dari sumber daya alam, tentu Pulau Jawa tidak lebih kaya dari Pulau Sumatera. Namun sumber daya alam tidak selamanya faktor penentu perekonomian. Sumber daya politik sering kali lebih penting daripada sumber daya alam. (Malan Abdullah, 2012), Gubernur Bank Indonesia tahun 2017 pernah mengatakan bahwa penyumbang tertinggi ekonomi Indonesia adalah Jawa dan Sumatera, 59\% dari jawa, $22 \%$ dari Sumatera, sisanya $19 \%$ dari luar Jawa dan Sumatera.

Dalam perkembangannya, mahasiswa Patani kuliah di Medan, dapat dipahami selain faktor selektivitas akademik juga karena faktor geografis. Jika dilihat dari peta laut, daerah Patani yang paling dekat dengan Sumatera, yaitu Provinsi Setun. Provinsi Setun dengan Lhokseumawe jaraknya 347, 16 KM. Setun lewat jalur laut ke Banda Aceh 536, 97 KM. Setun ke Belawan, 344,62 KM. Dengan demikian, dari sisi geografis Medan adalah tempat kuliah di Indonesia bagi mahasiswa Patani yang paling dekat. Di sisi lain, di Lhokseumawe pun perguruan tinggi pada saat itu tidak ada yang maju, mereka pun banyak kuliah ke Medan atau Banda Aceh. Selain itu, tidak ada jalur transfortasi dari Patani ke Lhokseumawe maupun Banda Aceh baik lewat laut maupun udara.

Jika dibandingkan dengan Banda Aceh, Universitas Syah Kuala baru berdiri 2 September 1961, lebih muda dari USU hampir 4 tahun. Tetapi IAIN Ar-Raniry telah berdiri tahun1963, lebih tua 10 tahun dari IAIN Sumatera Utara. Sementara Cikal Bakal IAIN Ar-Raniry telah berdiri sejak tahun 1960 cabang IAIN Yogyakarta. Lebih 
awal berdiri IAIN di Banda Aceh secara logis mengingat sejarah Islam yang awalnya dari Aceh. Kemudian berdirinya IAIN Palembang tahun 1964, sebagai faktor sejarah kejayaan Sriwijaya di Nusantra yang pusatnya di Palembang. Adapun berdirinya IAIN Imam Bonjol 29 Nopember 1966, sebuah pemikiran logis perkembangan Islam setelah dari Aceh pertama kali berkembang di Sumatera Barat.

\section{Penyebaran Mahasiswa Patani Di Seluruh Indonesia 2013-2019}

Sejarah baru bagi PTKIN untuk kedatangan mahasiswa Patani di seluruh Indonesia. Mereka selain menyebar di Pulau Jawa dan Sumatera, mereka juga kuliah di Pulau Sulawesi dan Kalimantan. Kehadiran mereka itu, amunisi bagi perguruan tinggi untuk mendapat akreditasi bagus dalam poin mahasiswa asing. Mahasiswa Patani datang ke Indonesia di masa pentingnya akreditasi Perguruan Tinggi. Badan Akreditasi Nasional Perguruan Tinggi (BAN PT) didirikan pada tahun 1994 untuk menilai kualitas perguruan tinggi. Sebab jika tidak ada peniaian kulaitas, maka masyarakat tidak mengetahui perguruan tinggi yang berkualitas.

Tanpa BAN PT bisa saja perguruan tinggi tidak punya target, sehingga kualitas pendidikan tinggi tidak terkontrol, apalagi setelah tahun 2001, 7 tahun sejak kelahirannya. Kualitas perguruan tinggi swasta tidak lagi di bawah dikontrol oleh perguruan tinggi negeri. Sebelum tahun 2001, semua perguruan tinggi swasta harus Ujian Negara Cicilan yang dikelolah oleh Perguruan Tinggi Negeri. Sejak tahun 2001, terjadi perubahan besar dimana Perguruan Tinggi Swasta menjadi mendiri menyelenggarakan ujian dan menentukan kelulusan kesarjanaan. Sejak tahun inilah bisa ditelusuri sejarah banyaknya ijazah palsu di Indonesia.

Pasca tahun 2001, Undang-Undang BAN PT diperbaharui untuk menjaga kualitas pendidikan. Perubahan Undang-Undang no. 12 Tahun 2012 tentang Perguruan Tinggi dan Permendikud No. 59 tahun 2012 tentang Badan Akreditasi Nasional. Sejak tahun inilah banyak perguruan tinggi Islam di Indonesia berusaha merekrut mahasiswa Islam dari Patani. Atas dasar kebutuhan Akreditasi Perguruan Tinggi inilah mahasiswa Patani direkrut oleh perguruan tinggi dan ormas Muhammadiyah dan sebagaian kecil oleh ormas NU. Muhammadiyah secara proaktif merekrut mahasiswa ke Patani dan membagi-bagikannya ke seluruh perguruan tinggi Muhammadiyah di Indonesia. Pada saat mahasiswa Patani direkrut, maka mereka itu mendapat beasiswa-beasiswa dari perguruan tinggi yang merekrut.

Pada tahun 2018 tercatat bahwa mahasiswa Patani kuliah di luar negeri yang terbanyak di Mesir dan kemudian Indonesia. Di Indonesia mereka menyebar di pulau 
Jawa, Sumatera, Kalimantan, dan Sulawesi. Ada juga informasi di Pulau Sumbawa. Kenapa perguruan tinggi Islam Indonesia merekrut mahasiswa Patani dan tidak merekrut mahasiswa Melayu lain seperti Malaysia, Singapura, Philipina, Brunei atau Negara minoritas Muslim lainnya seperti Burma atau Vietnam. Ini factor ekonomi, budaya, bahasa, dan kualitas pendidikan. Dari semua faktor tersebut mahasiswa Patani yang paling potensian direkrut.

Tahun 1960-an sampai 1980-an, pendidikan Indonesia lebih baik dari Malaysia. Namun pada tahun 1990-an pendidikan di Malaysia sudah banyak yang lebih baik dari Indonesia. Ada yang masih bisa diunggulkan oleh Indonesia dari Malaysia, yaitu pendidikan pesantren juga bidang-bidang teknik. Kenyataan ini bisa dilihat dari lebih banyak mahasiswa Indonesia yang kuliah di Malaysia daripada Mahasiswa Malaysia yang kuliah di Indonesia. Walaupun ada yang menilai bahwa pendidikan Islam di perguruan tinggi Indonesia lebih baik dari Malaysia, tetapi kemampuan ekonomi masyarakat mereka lebih memilih Negara lain yang dinialai lebih baik seperti studi di Timur Tengah bahkan di Eropa, Amerika, dan sebagainya. Begitu juga Singapura dan Brunei, faktor ekonomi dan kemampuan berbahasa asing, Indonesia tidak jadi destinasi pendidikan tinggi mereka, kecuali pesantren.

Kualitas Pesantren di Indonesia menjadi bukti bahwa pendidikan pada jenjang ini masih diminati. Banyak mahasiswa asing yang sekolah di pesantren-pesantren terbaik di Indonesia seperti Pondok Modern Gontor dan tidak ditemukannya santri Pesantren di Malaysia dan Brunei yang berasal dari Indonesia. Namun sejak Pandemi COVID-19, sebagian mahasiswa Patani yang terlanjut sudah pulang ke negaranya dan kemudian peraturan dari negera Thailand dan kebijakan sistem belajar di Indonesai yang masing online, maka mereka itu tidak pulang ke Indonesia dan tetap kuliah secara online. Di berbagai tempat yang peneliti kunjungi, hanya ada di tiga tempat sama sekali tidak ada lagi mahasiswanya di Indonesia, tetapi mereka tetap mahasiswa aktif di perguruan tinggi masing-masing dengan sistem belajar daring. Tempattempat itu, kota Kediri, Surabaya, dan Makassar.

Mahasiswa Patani yang berada di Kediri hanya kuliah di IAIN Kediri saja. Mereka tinggal dalam satu rumah dan kemudian mahasiswa tersebut tidak bisa pulang lagi. Akhirnya yang punya kost mengontrakkan rumah itu kepada orang lain. Mereka yang kuliah di IAIN Kediri direkrut oleh pihak yang diutus oleh rektorat. Perguruan tinggi pada mulanya tahun 2014 memberikan beasiswa seperti di perguruan tinggi lainnya. Pada saat 2021, mereka hanya tinggal 15 orang sebagai mahasiswa aktif. 
Menurut seorang dosen, Fakultas Tarbiyah IAIN Kediri, Iskandar Tsani mayoritas mereka kuliah di Fakultas Tarbiyah, jurusan Pendidikan Agama Islam dan bahasa Inggris. Sebagian lainnya di Fakultas Dakwah dan Komunikasi Islam. Mereka seperti juga di tempat lain berkumpul dalam satu tempat kontrakan dan tidak bersatu dengan orang Indonesia. Tinggal hidup bersama dan bergaul dengan sesama orang Patani, ini umum terjadi di berbagai tempat di Indonesia. Walaupun mereka sendiri tetap bergaul dengan orang lain, tetapi budaya mereka memang demikian.

Sementara di Surabaya pun mahasiswa Patani tidak ada yang tinggal karena mereka pulang semua. Mahasiswa Patani banyak yang kuliah di Jawa Timur, selain di Surabaya, di Jember, Mojokerto, dan Kediri, Malang, dan Ponorogo. Di Malang dan Sulabaya, selain kuliah di PTKIN mereka juga banyak kuliah di Muhammadiyah. Malah di Malang, mahasiswa Patani lebih hampir sama banyaknya di UMM dan UIN Malang. Sementara di Mojokerto hanya kuliah di Muhammadiyah.

Di Ponorogo, mahasiswa Patani tidak punya organisasi, namun mereka lengkap semua ada dan tidak ada yang pulang. Kuliah di Unida Ponorogo, mahasiswa Patani berasal semua dari alumni Gontor. Semua mereka berasrama layaknya pesantren, itu sebabnya mereka tidak ada yang pulang. Sewaktu wawancara dengan K.H. Dr. Hidyatullah, ketua senat Unida, beliau mengatakan orang Patani telah ada di Gontor sejak tahun 1968. Mereka itu sebagian adalah anak-anak mujahid Patani. Dari dulu, mereka masuk di Gontor mendapat prioritas untuk diterima asal mengikuti prosedur, namun tetap diterima.

Perguruan Tinggi Agama Islam yang tidak merekrut mahasiswa Patani karena mereka jauh-jauh hari telah kuliah di tempat tersebut, yaitu UIN Syarif Hidayatullah Jakarta, UIN Sunan Gunung Djati, UIN Sunan Kali Djaga, UIN Sumatera Utara, UIN ArRaniry, Universitas Darussalam Gontor (Unida) Ponorogo, Universitas Serambi Mekah, dan Universitas Abul Yatama, Universitas Muhamadiyah Sumatera Utara, dan Univesitas Islam Sumatera Utara. Universitas yang ada di Jakarta, Bandung, Yogyakarta, Medan, Banda Aceh, baik negeri maupuan swasta mereka tidak merekrut mahasiswa Patani, tetapi mereka sendiri yang datang ke perguruan tinggi tersebut. Namun IAIN Padangsidimpuan, walaupun di Sumatera Utara, lewat rekrutmen kampus mereka kuliah di tempat tersebut.

Pada mulanya, untuk akreditasi tahun 2013, PTKIN didukung oleh Direktur Perguruan Tinggi Agama Islam untuk merekrut mahasiswa dari luar negeri dan mereka diberikan beasiswa. Pada saat itulah berbagai perguruan tinggi agama Islam Negeri berburu mahasiswa ke Patani. Pertimbangan "berburu" mahasiswa ke Patani 
mengingat hanya merekalah yang paling potensial untuk mau kuliah di Indonesia karena faktor bahasa, budaya, ekonomi, dan kualitas pendidikannya lebih rendah dari Indonesia, khususunya dalam bidang studi ilmu-ilmu keislaman.

Malaysia, Brunei, dan Singapura walaupun mereka orang Melayu budaya dan bahasanya bisa beradaptasi dengan Indonesia, tetapi kemampuan mereka menguasai bahasa Inggris karena jajahan Inggris justru lebih baik dari umumnya orang Indonesia, cenderung mereka kuliah di Eropa dan Amerika. Orang Malaysia banyak juga mereka yang kuliah di Timur-Tengah, khsusunya Mesir. Sebagian kecil orang Brunei juga ada yang kuliah di Timur Tengah. Khusus Brunei tidak banyak kuliah di luar negeri karena Sultan Hasanal Bulqiyah punya prinsip, "Buat apa kuliah di Amerika, dosen dari Amerika kita datangkan ke Brunei. Buat apa kuliah ke Inggris, dosen dari Inggris kita datangkan ke Brunei. Buat apa kuliah ke Mesir, dosen dari Mesir kita datangkan ke Brunei.". Dari prinsip kemampuan ekonomi dan kebijakan Sultan Hasanal Bulqiyah itu, perguruan tinggi di Brunei memiliki dosen-dosen hebat di dunia, termasuk orang-orang hebat dari Indonesia, termasuk di antaranya Prof. Dr. Mulyadhi Kartanegara.

Sejak tahun 2014 sampai tahun 2018, empat tahun, sekitar 500 mahasiswa Patani per tahun datang menyebar ke Indonesia, baik karena direkrut atau tidak. Bagi mereka yang memiliki tingkat ekonomi yang memadai dan kemampuan bersaingnya juga bagus, mereka umumnya tidak mengambil peluang beasiswa dari perguruan tinggi agama Islam yang menawarkan. Umumnya mereka memilih untuk memilih kuliah ke tiga kota terbesar, yaitu Jakarta, Bandung, dan Yogyakarta, baik di negeri maupun swasta.

\section{Diskusi}

Ada beberapa hal yang menarik didiskusikan tentang hasil penelitian ini, tentang kualitas perguruan tinggi di Thailand secara umum dan kemudian perguruan tinggi agama Islam secara khusus. Selanjutnya membandingkannya dengan Indonesia.

Atase Pendidikan KBRI Bangkok menyebutkan bahwa pendidikan di Thailand dari K sampai perguruan tinggi sistemnya mirip dengan Indonesia dan tidak terdapat perbedaan yang mendasar. Perbedaan yang signifikan terletak pada pendidikan vokasi. Di Thailand pendidikan vokasi atau SMK di Indonesia ditempuh lima tahun, sementara di Indonesia hanya 3 tahun (A.Malek, 1994). Di Thailand politeknik bukan institusi yang melahirkan lulusan akademik. Lembaga itu berfungsi institusi long life 
leaner yang memberikan sertifikat keahlian. Orang yang punya keahlian di bidang las contohnya, bisa diuji dalam lembaga itu dan jika lulus akan diberikan sertifikat. Di Indonesia banyak orang yang punya keahlian tidak lewat jalur pendidikan, tetapi lewat pengalaman. Keahlian yang didapatkan lewat pengalaman seperti itu bisa mengusulkan ke politeknik untuk mendapatkan pengakuan berupa sertifikat.

Thailand memberlakukan wajib belajar 9 tahun, tetapi pendidikan gratis sampai tingkat SMA. Untuk menjamin mutu pendidikan dasar dan menengah di Thailand ditentukan oleh Ujian Nasional, hanya saja ujian ini tidak menentukan kelulusan peserta didik. Ujian nasional di Thailand berfungsi untuk perbaikan pendidikan secara nasional. Sementara kelulusan peserta didik ditentukan oleh sekolah masing-masing. Di Indonesia, Ujian Nasional selain untuk penjaminan mutu pendidikan sekaligus penentu kelulusan peserta didik.

Melihat sistem penjaminan mutu pendidikan pendidikan dasar dan menengah, penulis melihat lebih baik sistem di Thailand. Di Thailand penjaminan mutu bersifat provinsi, sementara di Indonesia bersifat negara. Thailand lebih realistis dan menghargai perbedaan kualitas pendidikan di berbagai daerah. Oleh sebab itu, kelulusan ditentukan oleh sekolah masing-masing. Yang menarik lagi dalam sistem pendidikan di Thailand perhatian pemerintah dengan Teknologi Informasi dan Komunikasi (TIK). Murid-murid difasilitasi dengan tablet komputer. Kenyataan inilah barangkali dasar alumni IAIN Padangsidimpuan yang dulu melaksanakan PPL di Patani mengatakan bahwa dalam bidang sains, Thailand lebih maju dari Indonesia.

Menariknya lagi, di Thailand walaupun kelulusan peserta didik otoritas sekolah, tetapi rekrutmen guru bersifat nasional. Dengan demikian, Thailand tetap menjaga kualitas guru secara nasional. Untuk meningkatkan mutu guru juga ada program peningkatan kualitas guru selama lima tahun. Untuk menjadi guru harus punya kualifikasi pendidikan sarjana. Pendidikan Tinggi di Thailand mirip dengan Indonesia, ada yang berada dalam naungan Kementerian Pendidikan dan ada Sekolah Dinas di Kementerian lainnya. Tentu yang berbeda, di Indonesia ada perguruan tinggi di bawah naungan Kementerian Agama. Hal ini dapat dimaklumi karena Indonesia bukan negera sekuler murni dan bukan juga negara agama. Melihat peringkat pendidikan tinggi negara-negara Asean, ranking Thailand masih di atas Indonesia. Indonesia peringkat lima sementara Thailand peringkat 4. Di bawah Indonesia ada Philipina, Kamboja, Laos, dan Miyanmar.

Tahun 2021, News and Word Report di Amerika Serikat membuat survei global berbasis persepsi tentang sistem pendidikan di negara-negara Asean, pertimbangan 
orang untuk kuliah, dan kualitas pendidikan, kembali lagi Indonesia peringkat 5 dibawah Thailand di peringkat 4.

Tabel 1. Peringkat Universitas ASEAN versi Webometrics tahun 2021

\begin{tabular}{|l|l|c|}
\hline \multicolumn{1}{|c|}{ No } & \multicolumn{1}{|c|}{ Nama Universitas } & Negara \\
\hline 1 & National University of Singapore & Singapura \\
\hline 2 & Universiti Malaya & Malaysia \\
\hline 3 & Nanyang Technological University & Singapura \\
\hline 4 & Universiti Teknologi Malaysia & Malaysia \\
\hline 5 & Chulalongkorn University & Thailand \\
\hline 6 & Universiti Putra Malaysia & Malaysia \\
\hline 7 & Universiti Sains Malaysia & Malaysia \\
\hline 8 & Mahidol University & Thailand \\
\hline 9 & Universitas Indonesia & Indonesia \\
\hline 10 & Chiang Mai University & Thailand \\
\hline 11 & Universiti Kebangsaan Malaysia & Malaysia \\
\hline 12 & Singapore Management University & Singapura \\
\hline 13 & Khon Kaen University & Thailand \\
\hline 14 & Kasetsart University & Thailand \\
\hline 15 & Singapore University of Technology and Design & Singapura \\
\hline
\end{tabular}

Dari rangking 15 universitas terbaik di ASEAN tersebut di atas, Indonesia hanya masuk satu universitas, yaitu Universitas Indonesia peringkat 9, sementara peringkat lima dan delapan universitas di Thailand. Universitas Chulanlangkorn pada mulanya tahun 1902-1916 masih berupa sekolah Kerajaan Thailand. Tahun 1917 berubah menjadi universitas. Ini adalah universitas tertua di Thailand. Universitas Mahidol berdiri tahun 1888 sebagai Sekolah Kedokteran Rumah Sakit. Tahun 1943 berubah menjadi Universitas Ilmu Kedokteran. Universitas ini lebih muda dari Universitas Chulalangkorn.

Jika dihubungkan dengan sejarah awalnya mahasiswa Patani datang ke Indonesia kuliah di Universitas Indonesia, Jurusan Hubungan Internasional, maka destinasi kuliahnya masih tepat. Sebab sampai tahun 2021, di Universitas Chulalangkorn belum ada jurusan Hubungan Internasional. Dengan demikian, kehadiran Mukhtar Muhammad tahun 1963 ke Indonesia untuk kuliah dari sisi 
peluang masih dinilai tepat karena di Thailand tidak ada jurusan Hubungan Internasional.

Berikutnya, perguruan tinggi Islam baru ada di Thailand tahun 1998, yaitu Universitas Fatoni. Pada tahun 2018, universitas ini baru punya empat fakultas Fakultas Pengajian Islam dan Undang-Undang (PAI), Fakultas Sastra dan Sains Kemasyarakatan, Fakultas Sains dan Teknologi, dan Fakultas Pendidikan (Yulianto, 2018). Universitas Fatoni adalah universitas Islam pertama yang berdiri di Patani. Tahun 2018, mahasiswanya berjumlah 4000 orang. Di Indonesia STAIN pun biasanya bisa punya mahasiswa sebanyak 4000 orang. Pada tahun 2000 berdiri Jamiah Islamiyah Daud al-Fathani di Yala. Sampai sekarang di JISDA terdapat empat fakultas, yaitu Tarbiyah, Syariah, Ushuluddin, dan Dirasat Islamiyah Arabiya (A.Malek, 1993)

Dari uraian singkat di atas tentang Studi Islam di Thailand, maka sangat pantas mereka melanjutkan kuliah ke luar negeri. Sementara kenapa harus ke Indonesia, telah terjawab di atas bahwa di Indonesia lebih murah biaya kuliah, biaya hidup, izin tinggal, dan budayanya lebih ramah dibandingkan dengan Malaysia. Alasan lainnya, Indonesia tidak berbatasan langsung dengan Thailand, sehingga tidak terjadi tawarmenawar politik dengan Indonesia untuk stabilitas keamanan negara.

\section{Kesimpulan}

Penelitian ini berkesimpulan sebagai berikut:

1. Sejak tahun 1963-1991, mahasiswa hanya kuliah di Pulau Jawa di kota Jakarta, Bandung, dan Yogyakarta. Pilihan tempat kuliah tersebut, mereka meyakini bahwa kuliah di tiga kota tersebut bagus dan berkualitas, termasuk lebih berkualitas dibanding di Malaysia sekalipun. Mereka, kuliah dengan biaya sendiri.

2. Tahun 1992-2013, mahasiswa Patani kuliah di Pulau Jawa di kota Jakarta, Bandung, dan Yogyakarta. Kemudian mereka juga sudah ada yang kuliah di Medan dan juga di Banda Aceh. Pilihan kuliah di Medan dan Banda Aceh secara khusus karena faktor kedekatan geografis. Lebih khusus, kuliah di Banda Aceh mereka merasa nyaman dan harmonis karena faktor psikologis bahwa Islam ke Patani diketahui dan diyakini mereka datang dari Aceh.

3. Tahun 2014-2019, mahasiswa yang kuliah sudah menyebar ke seluruh Indonesia. Selain di Jakarta, Bandung, Yogyakarta, Medan, dan banda Aceh. Umumnya mereka datang ke selain tempat yang disebutkan karena faktor beasiswa. Begitu beasiswa berhenti, maka gelombang mahasiswa berkurang, tetapi ke 5 kota 
terdahulu dan kota-kota besar di Jawa masih tetap berlanjut banyak walaupun dengan biaya sendiri.

\section{Pengakuan}

Artikel ini adalah hasil penelitian BOPTN Kementerian Agama tahun 2020 ongoing dengan klaster Kolabora AntarperguruanTinggi yang berjudul Studi Islam Mahasiswa Patani di Indonesia Tahun 1963-2019, dengan anggaran Rp. 100.000.000.

\section{DAFTAR PUSTAKA}

A.Malek, M. Z. (1993). Umat Islam Patani: Sejarah dan Politik. Hizbi Shah Alam.

A.Malek, M. Z. (1994). Patani dalam Tamaddun Melayu. Kementerian Pendidikan Malaysia.

Al-Fatani, A. F. (1994). Pengantar Sejarah Patani. Pustaka Darussalam.

Malan Abdullah. (2012). Jejak sejarah Abdus-Samad al-Palimbani. IAIN Raden Fatah.

Maragustam. (2018). Filsafat Pendidikan Islam Menuju Pembentukan Karakter. Pascasarjana UIN Sunan Kalijaga.

MPA. (2020). Modul PMIPTI 2020-2021. PMIPTI.

Rusma, S. (2019). Mahasiswa Patani di Kota Medan. USU. 